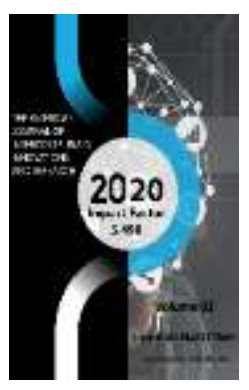

\title{
Development Of Ecotourism In The Nurata Ridge
}

\section{Bekzod Bekpulatovich Khakimov}

Teacher Of The Department Of Geography And Fundamentals Of Economics JSPI, Uzbekistan

Journal Website: http://usajournalshub.c om/index,php/tajiir

Copyright: Original content from this work may be used under the terms of the creative commons attributes 4.0 licence.

\section{ABSTRACT}

Natural monuments and historical monuments in the Nurata ridge have been studied and evaluated in terms of ecotourism development.

\section{KEYWORDS}

Nurata ridge, Ukhum, Majurum, Hayotboshi peak, Etimtog, Istiqlol park, Sovurbel pass, Khanbandi dam, Eastern biota.

\section{INTRODUCTION}

In the western part of the Turkestan ridge are the Nurata Mountains. The length of Mount Nurata is $264 \mathrm{~km}$ from the city of Jizzakh to its westernmost edge. The northern slope of Mount Nurata rises sharply from the foothills, with the highest point being the Peak of Life (2169 m), where the Ukhum and Majurum rivers begin. Life Peak is located in the central part of the mountain. The central part of the mountain is higher than the eastern and western parts, with an average height of 1,750 $\mathrm{m}$. In this section, in addition to the peak of Hayotboshi (2169 m), there are also peaks such as Katta(big) Fozilmon (2134 m), Qarchigay $(2105 \mathrm{~m})$. The western edge turns into hills with an absolute height of 400-450 meters on the meridian of the city of Nurata and gradually merges with the Kyzylkum Desert. The eastern 
wing enters the territory of Jizzakh in the form of a low mountain (Etimtog) at an altitude of 650-700 meters [1. Alibekov L].

\section{THE MAIN PART}

At present, Istiqlol Park has been built in Etimtog for children. The Istiqlol Park has a variety of attractions, a swimming pool, a carousel and a small zoo. At the highest point of the Etimtog there is a cozy bar with a unique design built of wood, reminiscent of a windmill in appearance. Etimtog can be called the Eiffel Tower in Jizzakh. The reason is that anyone who comes here has the opportunity to see the whole city. The number of visitors would have increased even more if several binoculars had been installed to make the city and its surroundings more convenient for spectators.

The south-eastern part of the northern Nurata Mountains is occupied by Mount Koytash. Koytash Mountain runs from the Sovurbel Pass in the northwest to the Sangzor River in the southeast. The length of Koytash mountain is $70 \mathrm{~km}$, the average height is $1260 \mathrm{~m}$ [2. Gudalov $\mathrm{M}$.

Sovurbel Pass (1162 m) connects the northern parts of Forish district and the district center Bagdan with the settlements in the southern parts of the district. Sovurbel Pass captivates with its natural beauty in spring. Teahouses have also been built on the northern slope of the Sovurbel Pass for passengers to relax. Since there are a lot of passers-by (about 1,000 people a day), it is necessary to build recreation areas and campsites. It has also been observed that in some years, when the winter is severe, the pass is covered with heavy snow and traffic stops [3. Gudalov M].
The Khanbandi Dam, built during the Karakhanid rule in the late 1oth century on the slopes of Mount Khanbandi, which belongs to the northern Nurata mountain systems, has survived to the present day. The Khanbandi Dam is located on the northern slope of Bandi Town, Forish District. The Khanbandi dam is built of crushed granite stones blocking the entrance to the gorge. The lower part of the Khanbandi Dam is 24.35 meters shorter and the upper part is 51.75 meters. The dam is $\mathbf{1 5 . 2 5}$ meters high and forms a $1.5 \mathrm{~km}$ long reservoir when flooded (Aga Burgutli, 2008). The Khanbandi Dam is full in the spring months and the water flows down the hill in the form of a waterfall. This waterfall in the Khanbandi Dam is about $52 \mathrm{~m}$ high and $15 \mathrm{~m}$ high. According to experts, the dam is the oldest in Central Asia, built by the ancient peoples of Turan.

At this point, Khanbandi Falls can be compared to Victoria Falls in Africa. True, Victoria Falls, located in a humid tropical forest, is several times larger in size (width $1800 \mathrm{~m}$ and height $120 \mathrm{~m}$ ) and water volume than Khanbandi Falls. But there are similarities in terms of charm. While Victoria Falls is famous for its humming sounds, it is famous for being visible from long distances as it is surrounded by bare plains around Khanbandi Falls. Khanbandi waterfall gives life to the arid region in spring and early summer. Many local tourists visit Khanbandi Falls in the spring to see and relax.

In the future, if an eco-route project is developed, which includes a tour of the Khanbandi waterfall and the adjacent Nurata mountains, as well as the Aydar-Arnasay lake system, this would become one of the most attractive destinations for foreign and domestic tourists [4. Gudalov M]. 
Such a hydraulic structure, built by our ancestors in ancient times for the purpose of collecting water, can still be used today. River water and flood waters should be prevented from flowing in the spring, to no avail. To do this, it is necessary to build dams similar to the Khanbandi Dam discussed above, taking into account the volume of runoff. Dams can prevent floods (e.g., the devastating floods of 2012 in the Gallaorol district) and improve economic efficiency by improving the irrigation system of agricultural lands and livestock in the summer when water is scarce.

Majrumsoy is one of the wettest rivers in the Nurata ridge. The Eastern Biota has also been preserved in the village of Majerum, located in the middle reaches of the Majrumsay. This biota, which is more than two thousand years old, is called "green tree" by the local people. Its circumference is almost 10 meters. These perennial fruit and ornamental trees are one of the objects taken under the protected area of Nurata Nature Reserve as a natural monument [5. Gudalov M].

According to experts, in the distant past, such spruces were abundant in the area of Mount Nurata, especially in the mountains around the village of Majerum, which is located at its highest point. Due to the lack of protection of mountain spruces and their use as a building material and firewood, spruce trees have sharply decreased. The only surviving spruce from those ancient times is located in the middle of the village of Majerum, and it was this condition that was the basis for its preservation. It is said that when Alexander the Great came from the west and began to march to Ustrushan, he rested with his soldiers under this tree [8. Khakimov].
In the scientific literature, this tree is called spruce, and it grows to a height of 1400-2500 meters. According to some data, the spruce lives more than two thousand years. Various parts of the spruce tree are also used in medicine. For example, various substances, essential oil, resin, sugar, wax and organic acids have been extracted from spruce domes. Tincture of the dome is used in medicine as a diuretic, expectorant and digestive aid. The essential oil of pine is used in the treatment of wounds.

In the villages of Ukhum, Sintobsoy and Ustun, as well as places associated with Alexander the Great, 1000-year-old trees are included in the list of state protection. Ancient rock paintings have been preserved in Osrafsoy of the reserve.

Andaginsay also flows from the central part of the Nurata ridge. There is a village of the same name in the middle reaches of the Andagin river. In the village of Andagin, one of the most revered shrines is the shrine of Hazrati Eshan Khalifa. The Hazrati Eshan Khalifa shrine is located $120 \mathrm{~km}$ north-west of Jizzakh and 45 $\mathrm{km}$ north-west of the district center, Baghdan. The natural landscape around the village is almost unchanged, the nature is extremely beautiful, high mountains, many wet springs [6. Sharipov Sh].

The shrine of Hazrati Eshan Khalifa is located in the middle of the village. The name of the saint who took this place as his last place and attained the status of a saint was Jalaliddin ibn Abdukarim. He is a sincere person who has worked hard to achieve the truth and the truth. He received an excellent education at the Mir Arab Madrasah in Bukhara, which was famous in his time, and studied the external sciences 
with interest. He was a sage of his time, a respected person, a lifelong observer of the essence of man and the universe, who dreamed of seeing the world as perfect, life as perfect, man as perfect. He was an example to others with his perfect faith, devoting his whole life to science, enlightenment and wisdom. The saint's rooms had nothing but old rugs, bookshelves, and pillows.

The current area of the shrine is about 0.5 hectares. This cultural heritage site is currently being reconstructed. There is a magnificent fountain in the courtyard of the shrine and a small pool has been built. Spring water has healing properties, from which always flows clear water. There are a lot of relict trout in the pond.

In recent years, the area around the shrine has been further beautified, and various spruce trees and flowers have been planted. There are several ancient mulberry and walnut trees in the courtyard of the shrine. The age of the old trees is about 250-300 years.

Indeed, there are many sacred sites in the Jizzakh oasis that encourage the people to be spiritually strong, to respect religious and national values, but they are known only at the local level, that is at the district or regional level. In order to develop pilgrimage tourism in the region, it is necessary to turn the monuments, which have gained the status of saints, into objects of cultural heritage of national and international level. It is they that serve as the basis for the development of pilgrimage tourism [7. Sharipov Sh].

It is known that pilgrimage tourism is the most acceptable and important type of travel that serves the spiritual of people. Because everyone believes, worships, and feels the need to purify himself spiritually and spiritually. In this regard, special attention should be paid to the development of pilgrimage tourism in the region in the near future. Therefore, the creation of favorable conditions in the holy shrines, the formation of modern infrastructure will serve to increase the number of pilgrims.

\section{CONCLUSION}

It is expedient to intensify research work on shrines in Jizzakh region, to include eligible shrines in religious tourist routes. To do this, it is important to pay attention to the following: -inclusion of all identified sacred sites in the state register;

-identification and mapping of objects of pilgrimage tourism; creating comfortable and necessary conditions for visitors; - to pay special attention to the promotion and advertising of sacred sites through the media;

-study of the experience of foreign countries with developed tourism, etc.

Many foreign tourists come to see the nature of these places, the shrines and the lifestyle of the locals. In order to serve tourists, 4 hotels have been established in the villages of Asraf, Andagin, Ukhum and Hayot.

\section{REFERENCES}

1. Alibekov L, Alibekova S, Hazarov I, Gudalov M. About some regularities of degradation geosystems in Central Asia. Tatranka Javorina, Slovakia, 2012, Vol 21, № $-1,42-44 r$

2. Gudalov M. Foundation of Aydar-Arnasay lakes system and their effects on the 
environmental landscape. Nature and Science.Volume 17, Number 11 November 25, 2019 USA New York.

3. Gudalov M., Zikirov B. Metnods of studying the landscapes around the Aydar-Arnasay lake system. International engineering journal for research \& development. Vol - 5, Issue - 7, 2020 India.

4. Gudalov M., Zikirov B., Imamova D. Predicting changes in landscares around the Aydar-Arnasay lake system. Accerted in the journal The American of Engineering and Technology. Volume - 02, Issue - 10, October 2020.

5. Gudalov M., Gozieva M. Ways to develor modern ecoturism in the Zamin basin. International engineering journal for research \& development. Vol - 5, Issue - 7, 2020 India.

6. Sharipov Sh, Gudalov M, Shomurodova Sh. Geolologic situation in the Aydar-Arnasay colony and its atropny. Journal of Critical Reviews. Volume 7, Issue 3, 2020 Malaysia Kuala Lumpur.

7. Sharipov Sh, Shomurodova Sh, Gudalov M. The use of the mountain kars in the tourism sphere in cort and recreation zone of Chimgan-Charvak. Journal of Critical Reviews. Volume 7, Issue 3, 2020 Malaysia Kuala Lumpur.

8. Khakimov Bekzod Bekpulatovich. THE NATURE OF THE NURATA RIDGE AND ITS PROTECTION. An International Multidisciplinary Research Journal. Vol. 10, Issue 10, October 2020.

9. Gudalov, M. (2019). Foundation of AydarArnasay lakes system and their effects on the environmental landscape. Nature and Science, 17(11).

10. Omonov, Q., \& Karimov, N. (2020). Importance Of Ancestoral Heritage. The
American Journal of Social Science and Education Innovations, 2(09), 196-202.

11. Karimov, N. R. (2020). A True Successor of Great Central Asian Scholars. Journal «Bulletin Social-Economic and Humanitarian Research,(7), 62-69.

12. Turakhanovna, S. U. (2020). The Issue of Literary Heroism in Korean Literature. Solid State Technology, 63(6), 1779-1785.

13. Kariev, A., \& Aminov, H. (2020). New information about Imam al-Zarnūjī and his work "Ta'līm al-Muta'allim". Solid State Technology, 63(6), 2372-2387. 